\title{
THE PREVALENCE AND ASSOCIATED DRIVERS OF PSYCHOACTIVE SUBSTANCE DEPENDENCE AMONG UNIVERSITY STUDENTS IN BANGLADESH
}

ROZPOWSZECHNIENIE SUBSTANCJI PSYCHOAKTYWNYCH WŚRÓD STUDENTÓW WYŻSZYCH UCZELNI W BANGLADESZU I CZYNNIKI PRZYCZYNIAJACCE SIĘ DO UZALEŻNIENIA OD SUBSTANCJI

Sardar Al Imran ${ }^{1}$ (D), Ayatullah Khan ${ }^{1}$ (ID), Shamim Ahmed ${ }^{2}$, Rashmia Sultana ${ }^{1}$, Sharmin Majumder ${ }^{4}$, Kamrul Hasan ${ }^{1}$, Sanju Karmokar ${ }^{1}$, Kazi Humayun Kabir ${ }^{1,3}$, Farhana Hoque ${ }^{1}$

${ }^{1}$ Development Studies Discipline, Khulna University, Bangladesh

${ }^{2}$ Dalla Lana School of Public Health, University of Toronto, Canada

${ }^{3}$ The University of Hong Kong

${ }^{4}$ Institute of Health Policy, Management and Evaluation, University of Toronto, Canada

\begin{abstract}
Introduction: The dangers of using various types of psychoactive drugs are well-known to university students all over the world. The current research sought to learn more about the prevalence of psychoactive drug abuse and its contributing factors among Bangladeshi university students.

Material and methods: A cross-sectional analysis was conducted among 400 university-level
\end{abstract}

\section{Streszczenie}

Wprowadzenie: Niebezpieczeństwa związane z używaniem substancji psychoaktywnych są dobrze znane studentom na całym świecie. Naszym celem było zbadanie rozpowszechnienia nadużywania substancji psychoaktywnych wśród studentów uniwersytetu w Bangladeszu, a także czynników, jakie mają w tym udział.

Materiał i metody: W okresie od listopada do grudnia 2019 roku przeprowadzono przekrojowe

Correspondence to/Adres do korespondencji: Sardar Al Imran, Development Studies Discipline, Khulna University, Khulna-9208, Bangladesh, phone: +8801757278811, e-mail: sardarimran1421@gmail.com

Authors' contribution/Wkład pracy autorów: Study design/Koncepcja badania: S. Al Imran, A. Khan, R. Sultana; Data collection/ Zebranie danych: S. Al Imran, A. Khan, R. Sultana, S. Karmokar, F. Hoque; Statistical analysis/Analiza statystyczna: S. Al Imran, A. Khan, K. Hasan; Data interpretation/Interpretacja danych: A. Khan, S. Ahmed, R. Sultana, S. Majumder, K. Hasan, S. Karmokar, K.H. Kabir; Acceptance of final manuscript version/Akceptacja ostatecznej wersji pracy: S. Ahmed, S. Majumder, K. Hasan, K.H. Kabir; Literature search/Przygotowanie literatury: S. Al Imran, S. Ahmed, S. Majumder, K.H. Kabir, F. Hoque

No ghostwriting and guest authorship declared./Nie występują zjawiska ghostwriting i guest authorship.

Submitted/Otrzymano: 21.12.2020 • Accepted/Przyjęto do druku: 09.07.2021

(c) 2021 Institute of Psychiatry and Neurology. Production and hosting by Termedia sp. z o.o.

This is an open access article under the CC BY-NC-ND license (http://creativecommons.org/licenses/by-nc-nd/4.0/) 
students who have consumed drugs 90 days prior to the study, in Khulna, Bangladesh from November to December 2019. Psychoactive substance dependence was measured using a self-reported 5-item Severity of Dependence Scale (SDS-5). The $\chi^{2}$ test of association and multinomial logistic regression is used to identify associated drivers of psychoactive substance dependence.

Results: More than two-thirds of the participants (77.8\%) were male, about half $(44.5 \%)$ were between 21 and 23 years of age and more than twothirds lived in urban areas (67.2\%). For mild, moderate and severe forms of psychoactive substance dependence, the average prevalence was $38.5 \%, 37.8 \%$ and $23.8 \%$ respectively. Age, sex, living situation, family economic situation, number of siblings, peer control, depression, academic performance, drug use for entertainment or relaxation and satisfaction with spending free time have all been described as major factors contributing to the occurrence of psychoactive substance dependence.

Discussion: The prevalence of psychoactive substance dependence among university students is on the rise and our research is one of the few studies that analyses contributing factors and identifies correlations between multiple critical factors among Bangladeshi university students.

Conclusions: To stop psychoactive substance use among university students in Bangladesh, some recommendations can be made on the significant factors associated with their substance use identified in this study.

Keywords: Drivers, Psychoactive substance dependence, University level students, Influence of peer, Bangladesh. badanie wśród 400 studentów wyższych uczelni w Khulna w Bangladeszu, którzy brali narkotyki w ciągu 90 dni przed badaniem. Uzależnienie od substancji psychoaktywnych mierzono wypełnianą samodzielnie 5-składnikową Severity of Dependence Scale (SDS-5). Test $\chi^{2}$ i wielomianowa regresja logistyczna posłużyły do identyfikacji czynników związanych z nadużywaniem substancji psychoaktywnych.

Wyniki: Ponad dwie trzecie uczestników $(77,8 \%)$ stanowili mężczyźni, około połowa $(44,5 \%)$ to osoby w wieku 21-23 lat, a ponad dwie trzecie $\mathrm{z}$ nich mieszkało na obszarach miejskich $(67,2 \%)$. Średnia częstość występowania łagodnych, umiarkowanych i ciężkich form uzależnienia od substancji psychoaktywnych wyniosła odpowiednio: $38,5 \%$, $37,8 \%$ i $23,8 \%$. Wiek, płeć, sytuacja życiowa, sytuacja ekonomiczna rodziny, liczba rodzeństwa, kontrola rówieśnicza, depresja, wyniki w nauce, używanie narkotyków dla rozrywki/relaksu oraz satysfakcja ze spędzania wolnego czasu zostały uznane za główne czynniki mające wpływ na powstanie uzależnienia od substancji psychoaktywnych.

Omówienie: Obserwuje się wzrost rozpowszechnienia uzależnienia od substancji psychoaktywnych wśród studentów uniwersytetu w Bangladeszu. Nasze badanie jest jednym z nielicznych, $\mathrm{w}$ którym analizuje się czynniki mające $\mathrm{z}$ tym związek, a także określa korelacje między wieloma kluczowymi czynnikami.

Wnioski: Aby powstrzymać używanie substancji psychoaktywnych przez studentów wyższych uczelni w Bangladeszu, należy opracować zalecenia dotyczące zidentyfikowanych $\mathrm{w}$ tym badaniu istotnych czynników związanych z używaniem tego typu substancji.

Słowa kluczowe: czynniki ryzyka, uzależnienie od substancji psychoaktywnych, studenci wyższych uczelni, wpływ rówieśników, Bangladesz.

\section{- INTRODUCTION}

The years spent at university are, in reality, a transitional period. Extreme educational tension, emergency life conditions, independence and isolation from parental guidance, autonomous decision making, sharing living space with strangers and interaction with unfamiliar cultures make the juggling social obligations with studies and personal responsibilities almost impossible [1-7]. Adolescence society emerges as a result of this departure from family values and opens the door to experimentation with psychoactive substances like nicotine, tobacco, cannabis, alcohol and other illegal drugs. As a result, the likelihood of using illicit drugs increases at this stage of life as students are 
becoming more vulnerable to the misuse of drugs $[2-5,8]$. The university students show a higher incidence of psychoactive substance dependence, which leads to poor educational performance and diminished performance later in life $[9,10]$.

Since young adults are an increasing vulnerable population for public health issues around the world, a growing body of study has looked at psychoactive drug abuse in university students and its negative impacts on their future. The rapid increase in psychoactive substance abuse in this population is seen as a pressing concern in both developed and developing countries [11-18]. Numerous observational studies have previously been conducted among university students in various countries to determine the prevalence and influencing factors of psychoactive substance dependence $[2,3,5,9,14,16,19-24]$. But no results have been found concerning prevalence except for various factors and, of the significant determinants, only peer pressure, depression and family income have been identified. Even though there are no findings like this for public universities, the available data from private university students in Bangladesh revealed that $66.87 \%$ of students have tried drugs on occasion while $33.13 \%$ of students have used drugs regularly [22].

Various influencing factors about psychoactive drug use and dependence among university students have been identified in various countries. Male [2, 5-7, 17, 19, 25, 26], upper- and middle-class families $[9,14,27]$, older generation $[2,9,23$, $25,28]$, living alone or away from family $[3,19,25]$ and having siblings [9] were some of the sociodemographic factors. In addition to peer control and friends' drug use [5, 13-15, 27], depressive symptoms $[2,7,20]$, poor academic performance $[9,15]$ and drug use for entertainment [13] were also significantly associated with psychoactive substance dependence among university-level students.

No studies have been carried out on the prevalence and critical factors associated with psychoactive substance use among Bangladeshi university-level students. This study comprises some part of the ongoing studies that aim to investigate the prevalence of psychoactive substance dependence among university students and the critical factors associated with their dependence in Bangladesh.

\section{- MAterial ANd METHOdS}

This cross-sectional analysis was carried out at the Khulna City Corporation in Bangladesh's south west region. Three public universities, four private universities, five medical schools, and more than fifteen colleges with 57,370 students make up the Khulna City Corporation [29].

Simple random sampling was used to calculate the sample size for this analysis, and 384 university-level students were needed as a sample though a total of 400 was included to compensate for any missed results. Data was collected from November to December 2019.

\section{Participants and procedure}

The participants were students 18 years of age or over enrolled in a bachelor's or master's degree programme who have consumed some form of psychoactive drug at least once in the previous 90 days. Students studying in the evening and executive classes were omitted from the study. The majority were in part- or full-time employment. However, we only included full-time students as study respondents. The research was conducted using convenience sampling techniques and an online self-reported questionnaire (created with Google Forms). The survey tool was distributed via social media.

This study was carried out among different university-level students so gaining approval from every institution was a challenge. For this reason, only Ph.D. researchers from different universities gave consent to carry out study. Informed consent was taken from the participants. Each of them read and understood the aim of the research and voluntarily agreed to take part. All information was confidentially gathered and processed and was only accessible to researchers. As this is not an uncommon issue, the names of the institutions were not used in the study to avoid the stigmatisation issues like harming the reputation of the institutions, student's personal life and so on.

\section{The outcome variable}

Psychoactive substance dependence was measured by the 5 -item Severity of Dependence Scale (SDS-5) [30]. This was a personally reported analysis of the situation with 5 items. Each of the items is scored on a four-point scale thus for 1-4 items: 0 - never/almost never, 1 - sometimes, 2 - often, 
Table I. Description of the sample $(N=400)$

\begin{tabular}{|c|c|}
\hline Characteristics & $n(\%)$ \\
\hline \multicolumn{2}{|l|}{ Age group (years) } \\
\hline $18-20$ & $85(21.2)$ \\
\hline $21-23$ & $178(44.5)$ \\
\hline$\geq 24$ & $137(34.2)$ \\
\hline \multicolumn{2}{|l|}{ Gender } \\
\hline Male & $311(77.8)$ \\
\hline Female & $89(22.2)$ \\
\hline \multicolumn{2}{|l|}{ Residence of family } \\
\hline Urban & $269(67.2)$ \\
\hline Rural & $131(32.8)$ \\
\hline \multicolumn{2}{|l|}{ Living status } \\
\hline Living alone/Hostel & $143(35.8)$ \\
\hline Students' hall & $112(28.0)$ \\
\hline With family & $145(36.2)$ \\
\hline \multicolumn{2}{|l|}{ Family economic status } \\
\hline Higher & $153(38.2)$ \\
\hline Middle & $142(35.5)$ \\
\hline Lower & $105(26.3)$ \\
\hline \multicolumn{2}{|l|}{ No. of siblings } \\
\hline None or 1 & $192(48.0)$ \\
\hline$>1$ & $208(52.0)$ \\
\hline \multicolumn{2}{|l|}{ Peer influence } \\
\hline Yes & $239(59.8)$ \\
\hline No & $161(40.2)$ \\
\hline \multicolumn{2}{|l|}{ Depression } \\
\hline Yes & $221(55.2)$ \\
\hline No & $179(44.8)$ \\
\hline \multicolumn{2}{|l|}{ Academic performance } \\
\hline Poor & $150(37.5)$ \\
\hline Average & $145(36.2)$ \\
\hline Excellent & $105(26.2)$ \\
\hline \multicolumn{2}{|l|}{ Entertainment/relaxation } \\
\hline Yes & $265(66.2)$ \\
\hline No & 135 (33.8) \\
\hline \multicolumn{2}{|c|}{ Satisfaction with free time } \\
\hline Yes & $173(43.2)$ \\
\hline No & $227(56.8)$ \\
\hline
\end{tabular}

3 - always/nearly always and for item 5: 0 - not difficult, 1 - quite difficult, 2 - very difficult, 3 - impossible. A total SDS scoring is accessible by adding scores for all items that ranged from a minimum of 0 to a maximum of 15 with higher total scores showing higher dependence levels. Fundamental
SDS score viewing rules recommend that $<5$ indicates mild, $<10$ moderate, and $\geq 10$ severe dependence. The overall score was then fragmented according to (SDS-5) rules. Evaluation of the issues and dependent psychoactive substance use can be challenging due to varying tolerance rates and also due to fairly limited biological symptoms of dependence syndromes like cannabis and alcohol abuse. Given this question, the World Health Organization recommends the Severity of Dependence Scale [30]. SDS-5 is a commonly used tool for determining psychoactive substance dependence among educational institution students and young people [31, 32].

\section{The independent variables}

Based on existing literature on determining factors for psychoactive substance dependence among university students, we included age, gender, class of education, institutions type, residency of family, living status, parental condition, family income, no. of siblings, the influence of peer, depression, academic performance, entertainment/ relaxation and satisfaction with free time as independent variables [9]. In terms of independent variables especially depression, entertainment and satisfaction with free time, the questions about the respondent's attitude were, for instance: $D o$ they feel depressed or not? Do they have any source of entertainment/relaxation or not? Do they have satisfaction with their free time or not? Prior to asking the question, some measurement scales were applied for validation for depression according to the Beck Depression Inventory (BDI) [33], for entertainment according to the Relaxation and Mindfulness Scale for Adolescents (EREMIND-A) [34] and for satisfaction according to the Satisfaction with Life Scale (SWLS) [35]. All the covariates are categorical, and their categories are listed in Table I with their identification code for categories.

\section{Statistical analysis}

Descriptive statistics were used to analyse the key characteristics of university students. Pearson's $\chi^{2}$ test was conducted to determine the relationship between psychoactive substance dependence and various factors involved. Finally, an empirical model was applied to determine the possible driving factors for acquiring drug dependence. All tests were performed by using SPSS.20 Windows version, which reported $p$-value 
Table II. Prevalence of various levels of psychoactive substance dependence among participants $(N=400)$

\begin{tabular}{|c|c|c|c|c|c|}
\hline \multirow[b]{2}{*}{ Characteristics } & \multicolumn{3}{|c|}{ Level of drug dependency } & \multirow[b]{2}{*}{$\chi^{2}$} & \multirow[b]{2}{*}{$p$-value } \\
\hline & $\begin{array}{l}\text { Mild } \\
38.5 \%\end{array}$ & $\begin{array}{c}\text { Moderate } \\
37.8 \%\end{array}$ & $\begin{array}{l}\text { Severe } \\
23.8 \%\end{array}$ & & \\
\hline \multicolumn{4}{|l|}{ Age group (years) } & 17.71 & $0.001^{\star *}$ \\
\hline $18-20$ & $25(29.4)$ & $45(52.9)$ & $15(17.6)$ & & \\
\hline $21-23$ & $66(37.1)$ & $57(32.0)$ & $55(30.9)$ & & \\
\hline$\geq 24$ & $63(46.0)$ & $49(35.8)$ & $25(18.2)$ & & \\
\hline \multicolumn{4}{|l|}{ Gender } & 15.28 & $<0.001^{* *}$ \\
\hline Male & $106(34.1)$ & $132(42.4)$ & $73(23.5)$ & & \\
\hline Female & $48(53.9)$ & $19(21.4)$ & $22(24.7)$ & & \\
\hline \multicolumn{4}{|l|}{ Residence of family } & 13.47 & $0.001^{\star *}$ \\
\hline Urban & $118(43.9)$ & $86(32.0)$ & $65(24.2)$ & & \\
\hline Rural & $36(27.6)$ & $65(49.6)$ & $30(22.9)$ & & \\
\hline \multicolumn{4}{|l|}{ Living status } & 61.13 & $<0.001^{* *}$ \\
\hline Living alone/Hostel & $34(23.8)$ & $90(62.9)$ & $19(13.3)$ & & \\
\hline Students' hall & $49(43.8)$ & $30(26.8)$ & $33(29.5)$ & & \\
\hline With family & $71(49.0)$ & $31(21.4)$ & $43(29.7)$ & & \\
\hline \multicolumn{4}{|l|}{ Family economic status } & 19.11 & $0.001^{\star *}$ \\
\hline Higher & $63(41.2)$ & $62(40.5)$ & $28(18.3)$ & & \\
\hline Middle & $43(30.3)$ & $48(33.8)$ & $51(35.9)$ & & \\
\hline Lower & $48(45.7)$ & $41(39.1)$ & $16(15.2)$ & & \\
\hline \multicolumn{4}{|l|}{ No. of siblings } & 9.20 & $0.010^{\star}$ \\
\hline None or 1 & $74(38.5)$ & $84(43.8)$ & $34(17.7)$ & & \\
\hline$>1$ & $80(38.5)$ & $67(32.2)$ & $61(29.3)$ & & \\
\hline \multicolumn{4}{|l|}{ Peer influence } & 26.37 & $<0.001^{\star *}$ \\
\hline Yes & $92(38.5)$ & $71(29.7)$ & $76(31.8)$ & & \\
\hline No & $62(38.5)$ & $80(49.7)$ & $19(11.8)$ & & \\
\hline \multicolumn{4}{|l|}{ Depression } & 22.75 & $<0.001^{\star *}$ \\
\hline Yes & $64(29.0)$ & $89(40.3)$ & $68(30.8)$ & & \\
\hline No & $90(50.3)$ & $62(34.6)$ & $27(15.1)$ & & \\
\hline \multicolumn{4}{|l|}{ Academic performance } & 19.76 & $0.001^{* *}$ \\
\hline Poor & $49(32.7)$ & $49(32.7)$ & $52(34.7)$ & & \\
\hline Average & $54(37.2)$ & $61(42.1)$ & $30(20.7)$ & & \\
\hline Excellent & $51(48.6)$ & $41(39.0)$ & $13(12.4)$ & & \\
\hline \multicolumn{4}{|l|}{ Entertainment/Relaxation } & 14.31 & $0.001^{* *}$ \\
\hline Yes & $110(41.5)$ & $83(31.3)$ & $72(27.2)$ & & \\
\hline No & $44(32.6)$ & $68(50.4)$ & $23(17.0)$ & & \\
\hline \multicolumn{4}{|c|}{ Satisfaction with free time } & 15.22 & $<0.001^{* *}$ \\
\hline Yes & $65(37.6)$ & $81(46.8)$ & $27(15.6)$ & & \\
\hline No & $89(39.2)$ & $70(30.8)$ & $68(30.0)$ & & \\
\hline
\end{tabular}

$p$-value obtained from Pearson $\chi^{2}$ test; ${ }^{*} p$-value $<0.05 ;{ }^{* *} p$-value $<0.01$.

$<0.05$ as statistically significant. However, we employed the widely used a multinomial logistic model to analyse the critical factors associated with psychoactive substance dependence as it [36, 37] allows likelihood determination in more than two groups of participants. 
Table III. Multinomial logistic regression analysis for a different level of psychoactive substance dependence

\begin{tabular}{|c|c|c|c|c|}
\hline \multirow{2}{*}{ Characteristics } & \multicolumn{2}{|c|}{ Moderate dependence } & \multicolumn{2}{|c|}{ Severe dependence } \\
\hline & OR $[\mathrm{Cl}]$ & $p$-value & OR $[\mathrm{Cl}]$ & $p$-value \\
\hline \multicolumn{5}{|l|}{ Age group (years) } \\
\hline $18-20$ & $1.46[0.69-3.08]$ & 0.320 & $1.68[0.65-4.35]$ & 0.270 \\
\hline $21-23$ & $1.14[0.62-2.11]$ & 0.653 & $3.09[1.50-6.35]$ & $0.002^{\star \star}$ \\
\hline \multicolumn{5}{|l|}{$\geq 24$ (ref.) } \\
\hline \multicolumn{5}{|l|}{ Gender } \\
\hline Male & $2.33[1.12-4.86]$ & $0.023^{*}$ & $2.83[1.23-6.53]$ & $0.014^{\star}$ \\
\hline \multicolumn{5}{|l|}{ Female (ref.) } \\
\hline \multicolumn{5}{|l|}{ Residence of family } \\
\hline Urban & $0.52[0.26-1.03]$ & 0.063 & $0.72[0.30-1.71]$ & 0.458 \\
\hline \multicolumn{5}{|l|}{ Rural (ref.) } \\
\hline \multicolumn{5}{|l|}{ Living Status } \\
\hline Living alone/Hostel & $4.17[2.08-8.35]$ & $<0.001^{\star *}$ & $0.50[0.20-1.26]$ & 0.146 \\
\hline Students' hall & $1.06[0.47-4.91]$ & 0.877 & $0.70[0.30-1.59]$ & 0.398 \\
\hline \multicolumn{5}{|l|}{ With family (ref.) } \\
\hline \multicolumn{5}{|l|}{ Family economic status } \\
\hline Higher & $0.83[0.40-1.69]$ & 0.613 & $1.00[0.41-2.46]$ & 0.985 \\
\hline Middle & $1.20[0.58-2.45]$ & 0.615 & $3.02[1.31-6.93]$ & $0.009^{\star *}$ \\
\hline \multicolumn{5}{|l|}{ Lower (ref.) } \\
\hline \multicolumn{5}{|l|}{ No. of siblings } \\
\hline None or 1 & $2.21[1.25-3.89]$ & $0.006^{\star *}$ & $0.46[0.24-0.91]$ & $0.026^{*}$ \\
\hline \multicolumn{5}{|l|}{$>1$ (ref.) } \\
\hline \multicolumn{5}{|l|}{ Peer influence } \\
\hline Yes & $0.58[0.33-1.01]$ & 0.055 & $3.67[1.80-7.47]$ & $<0.001^{\star *}$ \\
\hline \multicolumn{5}{|l|}{ No (ref.) } \\
\hline \multicolumn{5}{|l|}{ Depression } \\
\hline Yes & $2.28[1.23-4.21]$ & $0.006^{\star \star}$ & $3.45[1.75-6.79]$ & $<0.001^{\star *}$ \\
\hline \multicolumn{5}{|l|}{ No (ref.) } \\
\hline \multicolumn{5}{|l|}{ Academic performance } \\
\hline Poor & $0.53[0.26-1.09]$ & 0.086 & $4.82[2.01-11.57]$ & $<0.001^{\star *}$ \\
\hline Average & $0.55[0.27-1.13]$ & 0.108 & $2.07[0.82-5.22]$ & 0.122 \\
\hline \multicolumn{5}{|l|}{ Excellent (ref.) } \\
\hline \multicolumn{5}{|l|}{ Entertainment/Relaxation } \\
\hline Yes & $0.43[0.24-0.78]$ & $0.006^{\star *}$ & $2.70[1.30-5.61]$ & $0.008^{* *}$ \\
\hline \multicolumn{5}{|l|}{ No (ref.) } \\
\hline \multicolumn{5}{|c|}{ Satisfaction with free time } \\
\hline Yes & $1.62[0.91-2.88]$ & 0.098 & $0.50[0.24-1.03]$ & 0.063 \\
\hline No (ref.) & & & & \\
\hline
\end{tabular}

OR - odd ratio, $\mathrm{Cl}$ - confidence interval, ref. - reference, ${ }^{*} p$-value $<0.05,{ }^{* *} p$-value $<0.01$.

Reference category: Mild 


\section{- REsults}

\section{Distribution of factor variables}

The distribution of factor variables with general characteristics of the participants are presented in Table I showing that among 400 participants, more than two-thirds were male $(77.8 \%)$, nearly half were (44.5\%) between $21-23$ years of age and more than two-thirds of them were from an urban area (67.2\%). Accordingly, more than one-third of the participants lived alone or in a hostel (35.8\%), more than one-third were middle-class (35.5\%) and nearly half of the participants had either no or one sibling (48.0\%). More than half of the participants reported being under peer influence (59.8\%) and depressive (55.2\%) and nearly two-thirds used drugs for entertainment/relaxation (66.2\%). More than one-third have poor academic performance $(37.5 \%)$ and nearly half took psychoactive substances for free time satisfaction (43.2\%).

\section{Distribution of target variable level of dependence across categories of factor variables}

Table II also presents the prevalence of various levels of psychoactive substance dependence indication with existing variables. The overall prevalence of psychoactive substance dependence was $38.5 \%, 37.8 \%$, and $23.8 \%$ showing mild, moderate and severe respectively. The prevalence of both a moderate and severe level of psychoactive substance dependence was higher among participants aged 21-23, males, those living in an urban area, with depression and using drugs for entertainment/relaxation. Moreover, the prevalence of moderate psychoactive substance dependence was higher among participants living alone or in a hostel, from families of higher economic status, with no or one sibling, no peer influence, average academic performance and for free time satisfaction. Additionally, the prevalence of severe psychoactive substance dependence was higher among the participants living with parents, from a middle-class family, with more than one siblings, peer influence, poor academic performance and no free time satisfaction.

\section{Multinomial logistic regression analysis for various levels of psychoactive substance dependence}

Table III shows the results of multinomial logistic regression analyses exploring critical factors as- sociated with psychoactive substance dependence among participants in the past 90 days. The odds ratios determine that in participants with peer influence, the incidence of severe dependence was 3.67 times higher than in participants with no peer influence. Participants with depression were about 2.28 times and 3.45 times more likely to amplify moderate and severe dependence respectively than those without depression. Participants with poor academic performance were about 4.82 times severely dependent than those who had an excellent academic performance. Severe dependence was found about 2.7 times more frequently among participants who use drugs for entertainment or relaxation than those without an activity of this kind. In contrast, participants who used drugs for entertainment or relaxation were about $57 \%$ less likely to be moderately dependent than those who did not.

University-level students aged between 21 and 23 years of age were about 3.09 times more likely to experience severe dependence than those aged 24 and older. Among male participants, moderate and severe dependence was around 2.33 and 2.83 times higher respectively than among females. Also, the odds of moderate dependence were higher among participants who were living alone or in hostels and have no or one sibling compared with their counterparts. In contrast, participants with no or one sibling were about $54 \%$ less likely to be severely dependent than those with more than one siblings. Furthermore, participants from middle-class economic background families showed about 3 times the likelihood of severe dependence compared to the participants from lower economic background families.

\section{- Discussion}

Psychoactive substance dependence in Bangladesh, particularly in educational institutions, has now become predominant. The easy availability of numerous psychoactive substances, individual and group activity and other inappropriate behaviour have exacerbated the problem. While the prevalence of psychoactive substance dependence among university students is rising there is very little research investigating the factors linked to this prevalence and identifying the connections between multiple critical factors [7] among Bangladeshi university students. Nearly one-fourth (24\%) 
of the participants experienced severe dependence which is quite a lot lower than in the previous reports from Bangladesh (33\%) [22]. Severe dependence in our sample is higher than in university students from ASEAN countries (2.2\%) [3] as we have worked with various universities and with different students having different problems and also engaged in substance use in past 90 days. Therefore most of our students were marked as having more severe dependence than those from ASEAN country universities. Previous studies confirmed that the age (21-25) of the participants was significantly associated with psychoactive substance dependence among university students as evidenced in some cross-sectional studies [9, 14,23]. Similar to the previous study, we demonstrated that students aged between 21 and 23 years showed a more severe dependence than the students aged $\geq 24$ years old. It is unclear why students aged between 21 and 23 years were more likely to be severely dependent than students aged $\geq 24$. The structural variations in development of future friend communities, immediate liberty and independence from parental control and ignorance of potential family responsibility could be a plausible cause. More thorough research is suggested to investigate these maturity level-based disparities. Being male was found to be a significant critical factor for psychoactive substance dependence among university students, which supports findings from previous studies in Northern Ireland, Wales, and England, USA, Slovakia and Iran [2, 19, 20, 24]. Logistic regression models showed that being male raises the moderate and severe dependence by 2.33 and 2.83 times respectively. The findings have also shown that males were 2 to 4 times more likely to have a drug abuse problem than females in previous research $[2,38]$. This therefore presumably emerges from the fact that males use psychoactive substances at a greater rate, more frequently and more regularly because male students at university have a large circle with a different mentality and most suffer from various forms of mental pressure along with being more curious than female students.

Similar to previous findings, this study revealed that living alone in a hostel or away from family was a significant predictor for developing psychoactive substance dependence among university students $[3,19,25]$. The explanation probably lies in a strong reaction to the campus culture/environment (socialisation effect). Parental presence appears to be effective in protecting adolescents from problems with psychoactive substance dependence.

Past studies reported that the family income of university students was substantially linked to psychoactive substance dependence $[9,14,21]$. Findings from a study among high school students in Erbil City, Iraq documented that students with a good enough family economic status were more likely to drink alcohol than those from poorer family households [27]. Similarly, our study found that participants with the middle-class family economic status were more likely to show psychoactive substance dependence than those of lower-class family background. The likely social and psychological effects of deprivation are indeed a significant cause for this interaction; students may use a drug to alleviate a multiplicity of stress and anxiety like inadequate accommodation, a lack of affordable care and social discrimination. Also, psychoactive substances are not too costly in Bangladesh. The number of siblings was found to be important risk factors for psychoactive substance use among university students [9]. Our study also found that university students with several siblings were significantly related to psychoactive substance dependence as in Bajwa et al. study [9].

The results show that the influence of peers was an independent risk factor for developing psychoactive substance dependence. Those same findings have also been found this to be the biggest risk factor for participants [13, 27, 39]. It may be described as an occurrence that the individuals are susceptible to their peers' social control or encouragement. University students with depression or depressive symptoms showed a high level of psychoactive substance dependency [7, 20, 40-42]. Similarly, our study demonstrated that participants with depression were more likely to be both moderate and severe level psychoactive substance-dependent than those with no depression. It could be demonstrated that university students suffer from acculturating tension because of their cultural beliefs and their peer culture, which can contribute to anxiety and depression. Besides family problems, falling in love, being an average academic performer and so on could result in depression and developing psychoactive substance dependence. Additionally, poor academic performance was demonstrated as the important critical deter- 
minant for expanding psychoactive substance dependence among university students in the study. In our sample, poorly performing students were more at risk of consuming psychoactive substances than the academically successful as demonstrated by tobacco and alcohol usage findings among young persons in the USA and Australia $[43,44]$ and among students in Ethiopia [15, 45]. Furthermore, entertainment or relaxation was found to be a significant contributing factor for developing psychoactive substance dependence among university students, which was in line with the studies by Zeferino et al. and Kounenou $[13,46]$. It is worth mentioning that most of them treated it as a way of managing stress. Some cases also showed that most university students take psychoactive substances as a way of entertainment, believing they are not addicted because it is only entertainment. Especially students from first or second year think that substances are for entertainment, which leaves them vulnerable to gradual dependency and becoming caught in a cycle of substance abuse. The findings have a justified and important significance for creating a comprehensive approach to discourage the use of psychoactive substances by these young people.

\section{The limitations of the study}

First of all, a convenience sampling method was used for data collection among university-level students from specified universities in a city corporation of Bangladesh. Therefore findings from this study cannot be generalised to the university students of Bangladesh. Second, it was a cross-sectional analysis, so causal relationships cannot be ascertained from this analysis. Longitudinal research might be conducted to gain more accurate findings. Finally, this analysis was based on self-reported responses regarding experiences with drug use that cannot be supported by qualified data enumerators or experts.

\section{- CONCLUSIONS}

This study suggests a higher prevalence of psychoactive substance dependence among university students in Khulna, Bangladesh. Besides, it shows that age, male gender, living alone or in a hostel, middle-class family background, having siblings, peer influence, depression, poor academic performance and entertainment or relaxation are significantly associated with different levels of psychoactive substance dependence. Recognition of determinants linked to psychoactive substance dependence can be beneficial in designing multi-faceted interventions to mitigate psychoactive substance dependence and strengthen the physical and mental health of university students. Some recommendations can be made to prevent psychoactive substance use among university-level students in Bangladesh, like counselling can be added to the course with every student being obliged to participate in extracurricular activities and parents should be informed about their children's social environment.

\section{Acknowledgements/Podziękowania}

We would like to recognise the kind assistance of the participants during the data collection of this study. We also appreciate all the personnel for supporting the completion of this study and data collection./Pragniemy wyrazić wdzięczność za życzliwość, z jaką spotkaliśmy się ze strony uczestników badania w czasie zbierania danych. Wysoko cenimy również pomoc ze strony personelu placówek, w których prowadziliśmy badania.

\section{Conflict of interest/Konflikt interesów}

None declared./Nie występuje.

Financial support/Finansowanie

None declared./Nie zadeklarowano. 


\section{Ethics/Etyka}

The work described in this article has been carried out in accordance with the Code of Ethics of the World Medical Association (Declaration of Helsinki) on medical research involving human subjects, Uniform Requirements for manuscripts submitted to biomedical journals and the ethical principles defined in the Farmington Consensus of 1997.

Treści przedstawione w pracy są zgodne z zasadami Deklaracji Helsińskiej odnoszącymi się do badań z udziałem ludzi, ujednoliconymi wymaganiami dla czasopism biomedycznych oraz z zasadami etycznymi określonymi w Porozumieniu z Farmington w 1997 roku.

\section{References/Piśmiennictwo}

1. Sommet A, Ferrières N, Jaoul V, Cadieux L, Soulat J-M, Lapeyre-Mestre, et al. Use of drugs, tobacco, alcohol and illicit substances in a French student population. Therapies 2012; 67(5): 429-35.

2. El Ansari W, Vallentin-Holbech L, Stock C. Predictors of illicit drugs use among university students in Northern Ireland, Wales and England. Glob J Health Sci 2015; 7(4): 18-29.

3. Yi S, Peltzer K, Pengpid S, Susilowati IH. Prevalence and associated factors of illicit drug use among university students in the association of southeast Asian nations (ASEAN). Subst Abuse Treat Prev Policy 2017; 12: 9. DOI: https://doi.org/10.1186/s13011-0170096-3.

4. Steyl T, Phillips J. Actual and perceived substance use of health science students at a university in the Western Cape, South Africa. Afr Health Sci 2011; 11(3): 329-33.

5. Deressa W, Azazh A. Substance use and its predictors among undergraduate medical students of Addis Ababa University in Ethiopia. BMC Public Health 2011; 11(1): 660.

6. Gebreslassie M, Feleke A, Melese T. Psychoactive substances use and associated factors among Axum University students, Axum Town, North Ethiopia. BMC Public Health 2013; 13(1): 693 .

7. Tesfaye G, Derese A, Hambisa MT. Substance use and associated factors among university students in Ethiopia: a cross-sectional study. J Addict 2014. DOI: http://dx.doi. org/10.1155/2014/969837.

8. Locke GW, Shilkret R, Everett JE, Petry NM. Interpersonal guilt and substance use in college students. Subst Abus 2015; 36(1): 113-8.

9. Bajwa HZ, Al-Turki AS, Dawas AM, Behbehani MQ, Al-Mutairi AM, Al-Mahmoud S, et al. Prevalence and factors associated with the use of illicit substances among male university students in Kuwait. Med Princ Pract 2013; 22(5): 458-63.

10. Khattak M, Iqbal N, Khattak S, Ullah I. Influence of drugs on student performance: a qualitative study in Pakistan university students. Interdis J Contem Res Bus 2012; 4(8): 826-38.

11. Read JP, Wood MD, Davidoff OJ, McLacken J, Campbell JF. Making the transition from high school to college: The role of alcohol-related social influence factors in students' drinking. Subst Abus 2002; 23(1): 53-65. DOI: https://doi.org/10.1080/08897070209511474.

12. Simons JS, Gaher RM, Correia CJ, Hansen CL, Christopher MS. An affective-motivational model of marijuana and alcohol problems among college students. Psychol Addict Behav 2005; 19(3): 326. DOI: https://doi.org/10.1037/0893-164X.19.3.326.

13. Zeferino MT, Hamilton H, Brands B, Wright MDGM, Cumsille F, Khenti A. Drug consumption among university students: family, spirituality and entertainment moderating influence of pairs. Texto Contexto Enferm 2015; 24: 125-35.

14. Htet H, Saw YM, Saw TN, Htun NMM, Lay Mon K, Cho SM, et al. Prevalence of alcohol consumption and its risk factors among university students: A cross-sectional study across six universities in Myanmar. PLoS One 2020; 15(2): e0229329. DOI: https://doi. org/10.1371/journal.pone.0229329.

15. Birhanu AM, Bisetegn TA, Woldeyohannes SM. High prevalence of substance use and associated factors among high school adolescents in Woreta Town, Northwest Ethiopia: multi-domain factor analysis. BMC Public Health 2014; 14(1): 1186. DOI: https://doi. org/10.1186/1471-2458-14-1186. 
16. Makanjuola AB, Daramola TO, Obembe AO. Psychoactive substance use among medical students in a Nigerian university. World Psychiatry 2007; 6(2): 112.

17. Tavolacci MP, Ladner J, Grigioni S, Richard L, Villet H, Dechelotte P. Prevalence and association of perceived stress, substance use and behavioral addictions: a cross-sectional study among university students in France, 2009-2011. BMC Public Health 2013; 13(1): 724. DOI: https://doi.org/10.1186/1471-2458-13-724.

18. Tsering D, Pal R, Dasgupta A. Licit and illicit substance use by adolescent students in eastern India: Prevalence and associated risk factors. J Neurosci Rural Pract 2010; 1(02): 076-081. https://doi.org/10.4103/0976-3147.71721.

19. Heydari ST, Izedi S, Sarikhani Y, Kalani N, Akbary A, Miri A, et al. The prevalence of substance use and associated risk factors among university students in the city of Jahrom, Southern Iran. Int J High Risk Behav Addict 2015; 4(2): e22381.

20. Suerken CK, Reboussin BA, Sutfin EL, Wagoner KG, Spangler J, Wolfson M. Prevalence of marijuana use at college entry and risk factors for initiation during freshman year. Addict Behav 2014; 39(1): 302-7.

21. Silva LV, Malbergier A, Stempliuk VdA, Andrade AGd. Factors associated with drug and alcohol use among university students. Revista de Saúde Pública 2006; 40: 280-8.

22. Sani MN. Drug addiction among undergraduate students of private universities in Bangladesh. Procedia Soc Behav Sci 2010; 5: 498-501.

23. Damiri B, Sandouka HN, Janini EH, Yaish ON. Prevalence and associated factors of psychoactive substance use among university students in the West Bank, Palestine. Drugs Educ Prev Pol 2020; 27(2): 173-82.

24. Sebena R, Orosova O, Mikolajczyk RT, van Dijk JP. Selected sociodemographic factors and related differences in patterns of alcohol use among university students in Slovakia. BMC Public Health 2011; 11(1): 849. DOI: https://doi.org/10.1186/14712458-11-849.

25. Mohammadpoorasl A, Ghahramanloo AA, Allahverdipour H, Augner C. Substance abuse in relation to religiosity and familial support in Iranian college students. Asian J Psychiatr 2014; 9: 41-4.

26. Osman T, Victor C, Abdulmoneim A, Mohammed H, Abdalla F, Ahmed A, et al. Epidemiology of substance use among university students in Sudan. $J$ Addict 2016. DOI: https://doi.org/10.1155/2016/2476164.

27. Mahmood NA, Othman SM, Al-Tawil NG, Al-Hadithi TS. Substance use among high school students in Erbil City, Kurdistan Region: prevalence and potential contributing factors. East Mediterr Health J 2019; 25. DOI: https://doi.org/10.26719.19.022.

28. Peltzer K, Pengpid S. Correlates of illicit drug use among university students in Africa and the Caribbean. J Psychol Afr 2016; 26(4): 390-3. DOI: https://doi.org/10.1080/1433 0237.2016.1208961.

29. Bangladesh Bureau of Statistics (BBS). District Statistics 2011. Dhaka: Statistics and Informatics Division, Government of the People's Republic of Bangladesh; 2013. http://203.112.218.65:8008/WebTestApplication/userfiles/Image/District\%20Statistics/ Khulna.pdf (Accessed: 04.10.2021).

30. Gossop M, Darke S, Griffiths P, Hando J, Powis B, Hall W, et al. The Severity of Dependence Scale (SDS): psychometric properties of the SDS in English and Australian samples of heroin, cocaine and amphetamine users. Addiction 1995; 90(5): 607-14. DOI: https://doi.org/10.1046/j.1360-0443.1995.9056072.x.

31. Lawrinson P, Copeland J, Gerber S, Gilmour S. Determining a cut-off on the Severity of Dependence Scale (SDS) for alcohol dependence. Addict Behav 2007; 32(7): 1474-79.

32. Martin G, Copeland J, Gates P, Gilmour S. The Severity of Dependence Scale (SDS) in an adolescent population of cannabis users: reliability, validity and diagnostic cut -off. Drug Alcohol Depend 2006; 83(1): 90-3. DOI: https://doi.org/10.1016/j.drugalcdep.2005.10.014.

33. Richter P, Werner J, Heerlein A, Kraus A, Sauer H. On the validity of the Beck Depression Inventory. Psychopathology 1998; 31(3): 160-8. 
34. López-González L, Amutio A, Oriol X, Gázquez JJ, Pérez-Fuentes MdC, Molero MdM. Development and validation of the Relaxation-Mindfulness Scale for Adolescents (EREMIND-A). Psicothema 2018; 30(2): 224-31. DOI: 10.7334/psicothema2017.225.

35. Diener E, Emmons RA, Larsen RJ, Griffin S. The satisfaction with life scale. J Pers Assess 1985; 49(1): 71-5.

36. Bryan AE, Kim HJ, Fredriksen-Goldsen KI. Factors associated with high-risk alcohol consumption among LGB older adults: The roles of gender, social support, perceived stress, discrimination, and stigma. Gerontologist 2017; 57 (Suppl 1): S95-104. DOI: https://doi.org/10.1093/geront/gnw100.

37. Tesema AG, Kahsay ZH, Lemma GG, Gebretsadik WH, Weldemaryam MM, Alemayohu GG, et al. Prevalence of Factors Associated with and Level of Dependence of Psychoactive Substance Use among Mekelle University Students, Ethiopia. Int J Environ Res Public Health 2020; 17(3): 847-57.

38. Becker JB, Hu M. Sex differences in drug abuse. Front Neuroendocrinol 2008; 29(1): 36-47. DOI: https://doi.org/10.1016/j.yfrne.2007.07.003.

39. Ramirez R, Hinman A, Sterling S, Weisner C, Campbell C. Peer influences on adolescent alcohol and other drug use outcomes. J Nurs Scholarsh 2012; 44(1): 36-44.

40. Esmaeelzadeh S, Moraros J, Thorpe L, Bird Y. The association between depression, anxiety and substance use among Canadian post-secondary students. Neuropsychiatr Dis Treat 2018; 14: 3241.

41. Roshandel A, Safavi M, Kheiri ARZ. Prevalence of substance use and depression among the university students in Iran. Eur Psychiatry 2010; 25 Suppl 1: 1262.

42. Hamdan-Mansour AM, Halabi JO, Dawani HA. Depression, hostility, and substance use among university students in Jordan. Ment Health Subst Use 2009; 2(1): 52-63.

43. Hemphill SA, Heerde JA, Herrenkohl TI, Patton GC, Toumbourou JW, Catalano RF. Risk and protective factors for adolescent substance use in Washington State, the United States and Victoria, Australia: A longitudinal study. J Adolesc Health 2011; 49(3): 312-20. DOI: https://doi.org/10.1016/j.jadohealth.2010.12.017.

44. Beyers JM, Toumbourou JW, Catalano RF, Arthur MW, Hawkins JD. A cross-national comparison of risk and protective factors for adolescent substance use: the United States and Australia. J Adolesc Health 2004; 35(1): 3-16. DOI: https://doi.org/10.1016/j.jadohealth.2003.08.015.

45. Teshome D. Prevalence of substance use and its determinants among high school students in Addis Ababa. In: $22^{\text {nd }}$ Conference of the Ethiopian Public Health Association, 2011 Abstract Book, Addis Ababa: EPHA; 2011, p. 16-17.

46. Kounenou K. Exploration of the relationship among drug use and alcohol drinking, entertainment activities and self-esteem in Greek University students. Procedia Soc Behav Sci 2010; 2(2): 1906-10. 